ISSN 0258-7122 (Print), 2408-8293 (Online)

Bangladesh J. Agril. Res. 44(1): 89-101, March 2019

\title{
RESIDUAL BEHAVIOUR OF IMIDACLOPRID IN THE COUNTRY BEAN GROWING SOIL
}

\author{
H. RAHMAN ${ }^{1}$, T. AKTER ${ }^{2}$, H. K. MISHU ${ }^{3}$ \\ R. U. MIAH ${ }^{4}$ AND M. S. ALAM ${ }^{5}$
}

\begin{abstract}
The assessment of residual behavior of imidacloprid (Admire 20SL) in the soil of country bean agroecosystem and its risk assessment for consumption was studied. QuEChERS method was used for the extraction and clean-up of samples and the residues of imidacloprid was estimated using Gas Chromatography. The dissipation studies in the soil system were carried out by application of imidacloprid at five different dosages i.e. 100, 200, 300, 400, and $500 \mathrm{~g}$ a.i. ha ${ }^{-1}$. Average initial deposits of imidacloprid were found to be 0.99 , $1.33,1.62,1.83$ and $2.20 \mathrm{mg} . \mathrm{kg}^{-1}$. The residues reached below determination limit (BDL) of $0.01 \mathrm{mg} \mathrm{kg}^{-1}$ in 9 days for recommended dose and 12 days for remaining higher dosages. Half-life $\left(\mathrm{T}_{1 / 2}\right)$ ) of imidacloprid in the soil was observed to be $1.88,1.74,1.73,1.56$ and 1.52 days for $100,200,300,400$, and $500 \mathrm{~g}$ a.i. ha ${ }^{-1}$, respectively. The chemodynamics study of imidacloprid spray indicated that only $27.20-28.40 \%$ sprays were deposited to the target site (plant canopy) and 71.60-72.80\% were lost to non-target site such as soil and air. The drift of imidacloprid to soil (39.47-40.20\%) was higher than the air (32.13$32.60 \%$ ). Based on degradation pattern and maximum, the recommended preharvest interval (PHI) might be eight 9 days and a waiting period of two days might be suggested for reapplication of the imidacloprid in country bean agroecosystem.
\end{abstract}

Keywords: Imidacloprid, residue, soils, country bean agroecosystem.

\section{Introduction}

Safe food production depends on a number of factors, including the degradation of persistent chemicals applied in the agroecosystem. As pesticides are the most widespread agrochemicals, their frequent monitoring in agricultural produces and soils in which it was grown is essential (Durovic, 2011). It seems that soil contamination over a long period of time is the biggest problem in terms of food quality and food. The most frequent and harmful contamination of soil is caused by the use of pesticides and fertilizer. The pesticides penetrating the soil undergo chemical reactions and biochemical transformations (Borş et al., 2012). On the other hand, pesticides in the soil or subsoil are absorbed through complex processes such as: transfer of load, ionic exchange, and hydrophobic bonds. Soil particles, by means of clay-humic complex, represent an adequate support for

\footnotetext{
${ }^{1-4}$ Department of Entomology, Bangabandhu Sheikh Mujibur Rahman Agricultural University (BSMRAU), ${ }^{5}$ Department of Soil science, BSMRAU, Bangladesh.
} 
both pesticides adsorption and for some of their degradation by products, the adsorptive capacity depending on soil texture (Bors et al., 2012). Biological properties of soils, such as enzymatic activity and the total number of microorganisms in the soil, serve as a tool for assessment of soil quality change under the influence of various agrochemical processes, regarding the state of fertility for the diagnosis and certification of influence of the application of chemical fertilizers and pesticides on the global biological activity of soil (Liste, 2003).

Pesticide residues in agricultural produces are a fast-growing global problem with serious consequences on human health (Asmatullah \& Shakoori, 1998). The indiscriminate use of pesticides in Bangladesh has contaminated agricultural produces, waters, aquifers, wildlife, foods and feeds all over the country (Shammi et al., 2017)). Furthermore, irrational use of pesticides has created new pests that have never been a problem before (Haque et al., 2010). In this experiment, the widely-used pesticides in agricultural protection, Imidacloprid was selected. Imidacloprid constitute a family of neonicotinoids pesticides which cover a wide range of uses in the treatment of seed, soil and crops (Nunes et al., 1998). Imidacloprid is in toxicity class II - moderately toxic under the classification of EPA toxicity (Campbell et al., 2004). Although it has low mammalian toxicity, but residue levels in foodstuffs are generally legislated to minimize the exposure of consumers to the harmful or unnecessary intake of pesticides (Zeljezic et al., 2008).

Imidacloprid (I-[(6-chloro-3-pyridinyl)-methyl]-N-nitro-2-imidazolidinimine), is a systemic insecticide that acts as an insect neurotoxin and belongs to a class of chemicals called the neonicotinoids, which act on the central nervous system. Specifically, it causes a blockage of the nicotinergic neuronal pathway. By blocking nicotinic acetylcholine receptors, imidacloprid prevents acetylcholine from transmitting impulses between nerves, resulting in the insect's paralysis and eventual death. It is effective on contact and via stomach action. Because imidacloprid binds much more strongly to insect neuron receptors than to mammal neuron receptors, this insecticide is more toxic to insects than to mammals (Gervais et al., 2010). Other uses include application to foundations to prevent termite damage, pest control for gardens and turf, treatment of domestic pets to control fleas, protection of trees from boring insects and in preservative treatment of some types of lumber products (Herms et al, 2009).

Imidacloprid as a chloronicotinyl insecticide used to control biting and sucking insects. The insecticide is extremely potent against wide range of arthropods, including aphids, scale insects, whiteflies, pod borers, some heteroptera, coleoptera, and lepidoptera species (Decourtye et al., 2004). It is a soil or plantapplied insecticide used in a wide variety crops.

Recent research suggested the widespread agricultural use of imidacloprid may be contributing to honey bee colony collapse disorder, the decline of honey bee 
colonies (Chensheng et al., 2012 and Whitehorn et al., 2012). As a result, many countries have restricted use of imidacloprid and other neonicotinoids (Carrington, 2012). The European Food Safety Authority reported imidacloprid as a neonicotinoid pose an unacceptably high risk to honeybees (EFSA, 2013) and impairs its memory and brain metabolism (Decourtye et al., 2004).

The synthetic organic pesticide begins to degrade as soon as they synthesized. Liu et al. (2006) reported that imidacloprid was stable in water at neutral and acidic $\mathrm{pH}$ and slowly degraded in alkaline conditions. Vegetation also increased the dissipation rate of imidacloprid as well as its half-lives (Anhalt et al., 2007). The breakdown of principle component may be caused by harsh environmental condition, chemical interaction or photolytic reaction (Segura et al., 2008). Therefore, dissipation studies imidacloprid for a given crop in open field conditions of each growing area are necessary to test.

Country bean (Lablab purpureus L.) is an important year-round vegetable in Bangladesh. It has wide adaptability among the farmers because of its fast growth, high production with good nutritional quality. It was estimated the cultivated area of country bean in Bangladesh around 48000 ha with yield ranging from 10-12 t/ha (Rashid et al., 2007). The low production of the crop in the country could be attributed to several factors, the most important being the damage caused by the insect pests like Aphid (Aphis spp.), Pod borers (Maruca testularis \& Helicoverpa armigera), Leaf eating caterpillar (Plusia oricalchea), Hairy caterpillar (Spilarctia obliqua), Green semilooper (Plusia oricalchea), Hooded hopper (Leptocentrus Taurus), Leaf beetle (Madurasia obscurella), Bean bug (Coptosoma cribrarium) and Coreid bug (Leptoglossus spp). Since, Imidacloprid has a wide range action against insect pests, majority of the farmers of Bangladesh use this insecticide indiscriminately. The studies on the behavior of imidacloprid on various commodities like cabbage and cauliflower (Gajbhiye et al., 2004); eggplant (Mandal et al., 2010); corn (Bonmatin et al., 2005); sunflower (Laurent and Rathahao, 2003); soil and water (Liu et al., 2006) have been carried out but no study has been reported on the fate of imidacloprid in the soils of any agroecosystem. Therefore, the present investigation has been planned and designed to carry out in depth study on degradation pattern and risk assessment of imidacloprid in the soils of country bean agroecosystem.

\section{Materials and Methods}

The study was conducted during November 2016 to October 2017. Field experiment was done in the Entomological farm and laboratory analysis was done in the pesticide and environmental toxicology laboratory of Bangabandhu Sheikh Mujibur Rahman Agricultural University (BSMRAU), Gazipur. The experimental site is located at Madhupur Tract $\left(24^{\circ} 09^{\prime} \mathrm{N}\right.$ latitude and $90^{\circ} 26^{\prime} \mathrm{E}$ longitude) having an elevation of $8.2 \mathrm{~m}$ from sea level. 
Field experiment: Country bean crop was raised following recommended agronomic practices (Mondal, 2015). Imidacloprid (Admire 20 SL) was applied in the soil during flowering stage of the plant @ 100, 200, 300, 400 and $500 \mathrm{~g}$ a.i. ha $^{-1}$ with a control. About $250 \mathrm{~g}$ soil sample was collected randomly at $0(1 \mathrm{~h}), 1$, 3, 6, 9 and 12 days after the application of the insecticide. The country bean grown soil samples were collected from each plot separately, packed in polyethylene bags and brought to the laboratory for processing. Samples were extracted and cleaned up immediately after sampling.

\section{Chemodynamics study}

Determination of Imidacloprid in soil: For determining insecticide application loss in soil, a polythene sheet $\left(2.25 \mathrm{~m}^{2}\right)$ was initially placed randomly in the $1.5 \mathrm{~m}^{2}$ plot. Then the foam sheet $(1.25 \mathrm{~cm}$ thickness $)$ of the same size (weighed) was placed on the polythene sheet to avoid loss of applied insecticide to the ground. Immediately after application of insecticide, the foam was weighed by electric balance. Insecticide application loss in soil was determined by subtracting the initial weight from the final weight of the foam sheet.

Determination of Imidacloprid loss in air: The plots $\left(1.5 \mathrm{~m}^{2}\right)$ were housed by the polythene sheet. Underside of the roof of the house, $2.25 \mathrm{~m}^{2}$ foam sheet (weighed) was placed randomly. Immediately after application of insecticide, final weight of the foam sheet was taken by electrical balance and loss of insecticide in the air was measured from the difference between final and initial weight of foam sheet.

Determination of quantity of imidacloprid retained on plant canopy: Quantity of imidacloprid on plant canopy $=$ Total quantity of insecticide applied - (Quantity of Imidacloprid lost in the soil + Quantity Imidacloprid lost in the air).

Preparation of standard solution: A standard stock solution of imidacloprid (1 mg. $\mathrm{L}^{-1}$ ) was prepared in $\mathrm{GC}$ grade acetonitrile. The standard solutions required for constructing a calibration curve $\left(10,20,30 \mathrm{ngL}^{-1}\right)$ were prepared from stock solution by serial dilutions with GC grade acetonitrile. All standard solutions were stored at $4{ }^{\circ} \mathrm{C}$ before use.

Instruments: The quantification of imidacloprid residues was done by using Gas Chromatograph (GC) equipped with Electron Capture Detector (ECD), The residues of imidacloprid were confirmed using the standard chromatogram and retention time. The Gas chromatographic conditions are presented in the Table 1. 
Table 1. Details of gas chromatographic conditions using in this study

\begin{tabular}{|c|c|c|c|c|}
\hline \multirow{4}{*}{$\begin{array}{l}\text { Column } \\
\text { temperature } \\
\text { program }\end{array}$} & \multicolumn{4}{|l|}{ Condition } \\
\hline & $\begin{array}{l}\text { Column name } \\
\text { Column Lengt } \\
\text { Inner Diamete } \\
\text { Film thickness } \\
\text { Column Max }\end{array}$ & $\begin{array}{l}\text { Rtx-CL pesticide (S } \\
: 30 \mathrm{~m} \\
: 0.32 \mathrm{~mm} \\
0.50 \mu \mathrm{m} \\
\text { emp: } 340^{\circ} \mathrm{C}\end{array}$ & (726625) & \\
\hline & $\underline{\text { Rate }{ }^{\circ} \mathrm{C} / \mathrm{min}}$ & $\underline{\text { Temperature }\left({ }^{\circ} \mathrm{C}\right)}$ & $\underline{\text { Hold time (min) }}$ & $\begin{array}{l}\text { Total } \\
\text { Program }\end{array}$ \\
\hline & --- & 220 & 1.0 & $9 \min$ \\
\hline & 5 & 235 & 5.0 & \\
\hline $\begin{array}{l}\text { Oven } \\
\text { temperature }\end{array}$ & $280^{\circ} \mathrm{C}$ & & & \\
\hline $\begin{array}{l}\text { Injector } \\
\text { temperature }\end{array}$ & $280^{\circ} \mathrm{C}$ & & & \\
\hline $\begin{array}{l}\text { Detector } \\
\text { temperature }\end{array}$ & $300^{\circ} \mathrm{C}$ & & & \\
\hline Gas flow rate & Nitrogen as ca & rier, $30 \mathrm{~mL} \mathrm{~min}{ }^{-1}$ & & \\
\hline $\begin{array}{l}\text { Injection } \\
\text { volume }\end{array}$ & $2 \mu \mathrm{L}$ & & & \\
\hline
\end{tabular}

An aliquot was injected into the GC with auto injector. Tentative identification of the suspected insecticide was carried out in relation to retention times of the pure analytical standard.

Sample preparation, extraction and cleanup: A standardized analytical method with slight modification was followed for extraction of imidacloprid residues as reported by Sharma (2013). The soil samples were prepared following QuEChERS method for the determination of imidacloprid residues.

The collected soil samples $(250 \mathrm{~g})$ were dried under the sun. A sub sample of $10 \mathrm{~g}$ of soil was weighed into a $250-\mathrm{mL}$ conical flask and then $20 \mathrm{~mL}$ acetonitrile was dispensed into it. The sample was homogenized using high speed homogenizer (Heidolph Silent Crusher-M ${ }^{\circledR}$ ) for 2-3 min at 1400-1500 rpm to homogenize soil sample. $4 \mathrm{~g} \mathrm{MgSO}_{4}$ and $1 \mathrm{~g}$ Sodium chloride $(\mathrm{NaCI})$ was added to homogenize the sample for phase separation. Then the sample solution was covered with parafilm as acetonitrile is volatized in nature. The contents were centrifuged at $3300 \mathrm{rpm}$ for $5 \mathrm{~min}$. An aliquot of $20 \mathrm{ml}$ acetonitrile layer was transferred in a vial and then stored in $4^{\circ} \mathrm{C}$. The acetonitrile extract was then subjected to suspension mixture of primary secondary amine (PSA) $+\mathrm{MgSO}_{4}$ to clean up the sample. An aliquot of acetonitrile was transferred into a separatory funnel and nhexane was added to the aliquot and vigorously shaken for 1 minute. The layers 
were allowed to separate. Then acetonitrile was drained out and n-hexane remained in the separatory funnel. Then sulfuric acid was added to hexane so that microorganisms were killed. After 1-1.5 minutes, sulfuric acid drained out of the separatory funnel and distilled water added to the hexane to remove sulfuric acid from the aliquot. The aliquot was drained out through the bed of anhydrous sodium sulphate with a filter paper.

\section{Estimation by Gas Chromatograph}

An injection volume of $2 \mu \mathrm{L}$ was used in all the experiments. Residues of imidacloprid were quantified by comparison of peak height/peak area of standards with that of unknown or spiked samples run under identical conditions. Under these operating conditions the retention time of imidacloprid was found to be 8.295 min (Fig. 1).

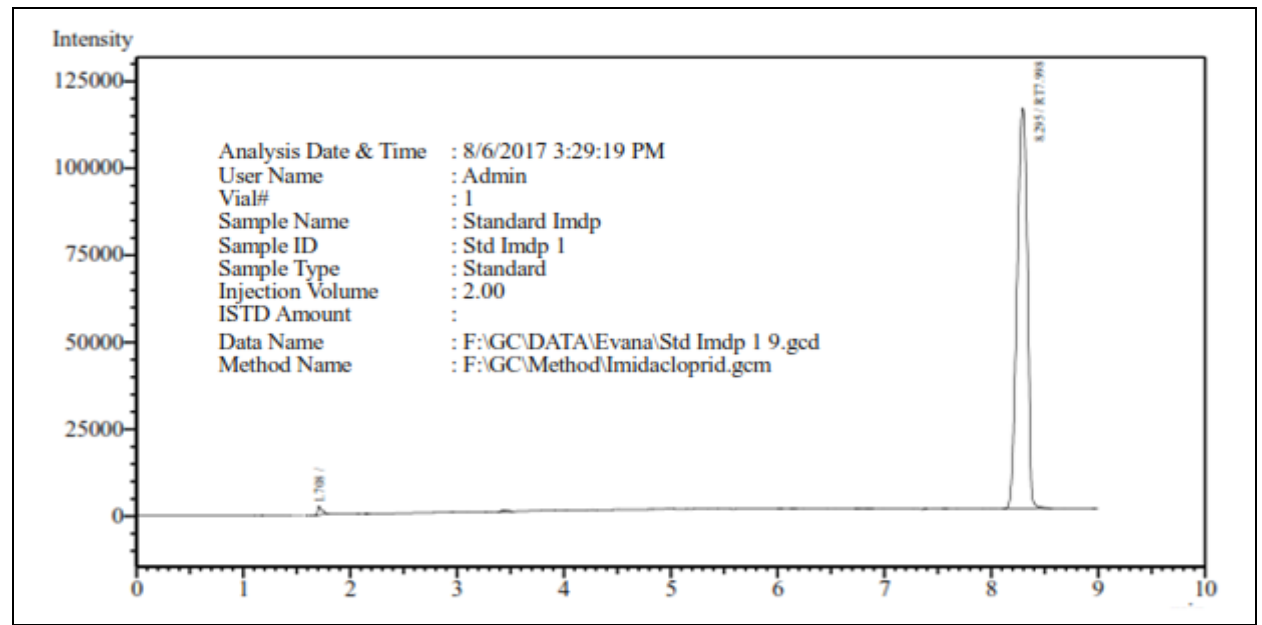

Fig. 1. Chromatogram of Imidacloprid insecticide standard.

Half-life of imidacloprid on country bean grown soil: The persistence of this insecticide is generally expressed in terms of half-life $\left(\mathrm{T}_{1 / 2}\right)$ or $\mathrm{DT}_{50}$ i.e. time for disappearance of pesticide to $50 \%$ of its initial concentration. The dissipation of imidacloprid on country bean soil follow first order kinetics. The Half-life value $\left(\mathrm{T}_{1 / 2}\right)$ is usually defined as the time required for half of the given quantity of material to dissipate (Gunther and Blinn, 1955). Half-life $\left(\mathrm{T}_{1 / 2}\right)$ of imidacloprid calculated by fitting first order kinetics as per Hoskins (1961) as

$$
\begin{aligned}
& C=C_{0 .} e^{-k t} \text { - } \\
& T_{1 / 2} \text { or } D T_{50}=\ln 2 . k^{-1}-
\end{aligned}
$$

Where $\mathrm{C}$ is the chemical concentration $\left(\mathrm{mg}^{\mathrm{kg}} \mathrm{kg}^{-1}\right.$ ) at time $\mathrm{t}$ (days) and $\mathrm{C}_{0}$ is the initial concentration $\left(\mathrm{mg} \cdot \mathrm{kg}^{-1}\right), \mathrm{K}$ is the first order kinetic constant at $\left(\mathrm{day}^{-1}\right)$ independent of $\mathrm{C}$ and $\mathrm{C}_{0}$. The Half-life value $\left(\mathrm{T}_{1 / 2}\right)$ was calculated using equation (2) with the obtained kinetics (K) from equation (1). 


\section{Results and Discussion}

Method development and validation: The recovery studies were carried out at different levels to establish the reliability and validity of analytical method and to know the efficacy of the procedures. The average recoveries of the imidacloprid from country bean soil samples at fortification level 0.01 to $0.10 \mathrm{mg} \cdot \mathrm{kg}^{-1}$ ranged from 85.27 to $90.57 \%$ (Table 2). The average recoveries values were found to be more than $85 \%$. Therefore, the results have been presented as such without converting by any correction factor. The precision of the method was determined by repeatability studies of the method and expressed by RSD values (relative standard deviation).

Table 2. Recovery and repeatability (RSD) of imidacloprid on country bean grown soil at different levels

\begin{tabular}{c|c|c|c|c}
\hline Insecticide & $\begin{array}{c}\text { Level of } \\
\text { fortification } \\
\left({\left.\mathrm{mg} \cdot \mathrm{kg}^{-1}\right)}^{*}\right.\end{array}$ & $\begin{array}{c}\text { Meanª recovery } \\
(\%)\end{array}$ & $\mathrm{SD}$ & RSD \\
\hline Imidacloprid & 0.10 & 90.57 & 1.57 & 1.63 \\
& 0.05 & 85.27 & 1.48 & 1.72 \\
& 0.01 & 87.38 & 1.55 & 1.75 \\
\hline
\end{tabular}

The RSD for repeatability, ranged from $1.63 \%$ to $1.75 \%$ different spiking levels as shown in Table 2. The quantification was accomplished by calibration curve prepared by diluting the stock solution. The assessment of linearity was done by statistical data obtained with correlation coefficient of 0.9989 (Fig. 2). Limit of quantification (LOQ) was found to be $0.01 \mathrm{mg} \mathrm{kg}^{-1}$ and limit of detection (LOD) being $0.003 \mathrm{mg} \cdot \mathrm{kg}^{-1}$. The cleaned-up procedure for this methodology was found to efficient since no significant matrix effect was observed.

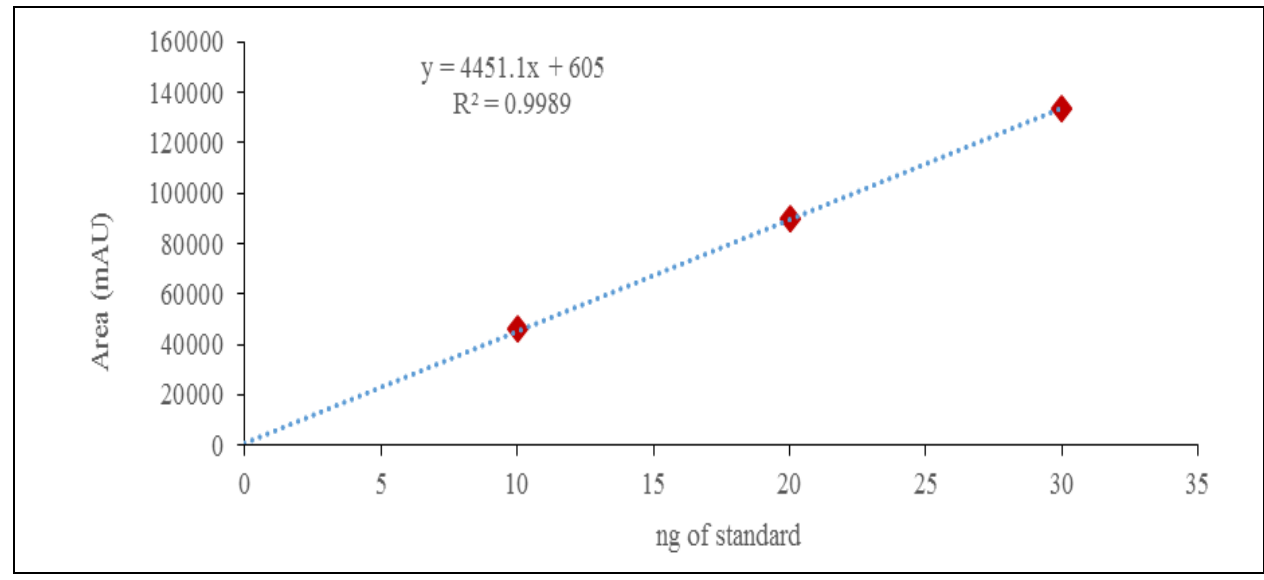

Fig. 2. Calibration curve of different concentrations of imidacloprid. 
Persistence of imidacloprid in soils of country bean agroecosystem: Average initial deposit of imidacloprid were found to be $0.99,1.33,1.62,1.83$ and 2.20 mg.kg-1 , following application @ 100, 200, 300, 400 and $500 \mathrm{~g}$ a.i. ha ${ }^{-1}$, respectively. The mean initial residues were reduced to more than $57 \%$ on one day. These residues were further reduced to more than $56 \%$ and $67 \%$ on $3^{\text {rd }}$ day and $6^{\text {th }}$ day, respectively.

Table 3. Residues of imidacloprid (mg. $\left.\mathrm{kg}^{-1}\right)$ in soil at different intervals and doses

\begin{tabular}{|c|c|c|c|c|c|}
\hline $\begin{array}{l}\text { Days after } \\
\text { treatment }\end{array}$ & $100 \mathrm{~g}$ a.i. ha ${ }^{-1}$ & $200 \mathrm{~g}$ a.i. ha ${ }^{-1}$ & $300 \mathrm{~g}$ a.i. ha ${ }^{-1}$ & $400 \mathrm{~g}$ a.i. $\mathrm{ha}^{-1}$ & $500 \mathrm{~g}$ a.i. ha ${ }^{-1}$ \\
\hline $\begin{array}{c}0 \text { ( } 1 \text { hour } \\
\text { after spray) }\end{array}$ & $0.99 \pm 0.125$ & $1.33 \pm 0.141$ & $1.62 \pm 0.097$ & $1.83 \pm 0.069$ & $2.20 \pm 0.090$ \\
\hline 1 & $\begin{array}{c}0.43 \pm 0.080 \\
\mathrm{a}(57.15)\end{array}$ & $\begin{array}{c}0.53 \pm 0.061 \\
(60.03)\end{array}$ & $\begin{array}{c}0.65 \pm 0.043 \\
(61.03)\end{array}$ & $\begin{array}{c}0.67 \pm 0.028 \\
(64.00)\end{array}$ & $\begin{array}{c}0.77 \pm 0.090 \\
(65.05)\end{array}$ \\
\hline 3 & $\begin{array}{c}0.19 \pm 0.012 \\
(56.06)\end{array}$ & $\begin{array}{c}0.21 \pm 0.011 \\
(60.70)\end{array}$ & $\begin{array}{c}0.22 \pm 0.010 \\
(65.35)\end{array}$ & $\begin{array}{c}0.24 \pm 0.012 \\
(63.95)\end{array}$ & $\begin{array}{c}0.30 \pm 0.016 \\
(61.31)\end{array}$ \\
\hline 6 & $\begin{array}{c}0.05 \pm 0.002 \\
(72.47)\end{array}$ & $\begin{array}{c}0.06 \pm 0.004 \\
(69.75)\end{array}$ & $\begin{array}{c}0.07 \pm 0.005 \\
(69.22)\end{array}$ & $\begin{array}{c}0.08 \pm 0.003 \\
(67.42)\end{array}$ & $\begin{array}{c}0.08 \pm 0.004 \\
(72.50)\end{array}$ \\
\hline 9 & $\begin{array}{c}{ }^{\mathrm{b}} \mathrm{BDL} \\
(100.00)\end{array}$ & $\begin{array}{c}0.06 \pm 0.007 \\
(90.15)\end{array}$ & $\begin{array}{c}0.07 \pm 0.003 \\
(60.28)\end{array}$ & $\begin{array}{c}0.08 \pm 0.003 \\
(60.40)\end{array}$ & $\begin{array}{c}0.08 \pm 0.003 \\
(56.31)\end{array}$ \\
\hline 12 & $\begin{array}{c}\text { BDL } \\
(100.00)\end{array}$ & $\begin{array}{c}\text { BDL } \\
(100.00)\end{array}$ & $\begin{array}{c}\text { BDL } \\
(100.00)\end{array}$ & $\begin{array}{c}\text { BDL } \\
(100.00)\end{array}$ & $\begin{array}{c}\text { BDL } \\
(100.00)\end{array}$ \\
\hline
\end{tabular}

${ }^{\mathrm{a}}()$ Percentage dissipation after spraying, ${ }^{\mathrm{b}} \mathrm{BDL}=$ Below determination limit $(<0.03 \mathrm{mg}$ $\left.\mathrm{kg}^{-1}\right)$

The residues reached below determination limit of $0.03 \mathrm{mg} \mathrm{kg}^{-1}$ at 9 days following application of imidacloprid @ $100 \mathrm{~g}$ a.i. $\mathrm{ha}^{-1}$. Imidacloprid residues were also found to be below the determination limit of $0.03 \mathrm{mg} \mathrm{kg}^{-1}$ in 12 days and thereby showing $100 \%$ loss following application of imidacloprid at all the dosages (Table 3).

The above findings revealed that higher rate of application of imidacloprid resulted in higher initial deposits. As with other insecticides, the residues of imidacloprid on country bean cultivated soil declined with time and fairly high rate of dissipation was observed. The results are in agreement with those of Zhang et al. (2012) who reported the fate of imidacloprid in rice field ecosystems after application@ $300 \mathrm{~mL}$ a.i. $\mathrm{ha}^{-1}$. The residues of imidacloprid on rice straw were $3.16,1.59$ and $1.20 \mathrm{mg} \mathrm{kg}^{-1}$ after $2 \mathrm{~h}, 8 \mathrm{~h}$ and 1 day, respectively. In rice straw, $0.008 \mathrm{mg} \mathrm{kg}^{-1}$ imidacloprid was found even in 20 days after the application of pesticide. 


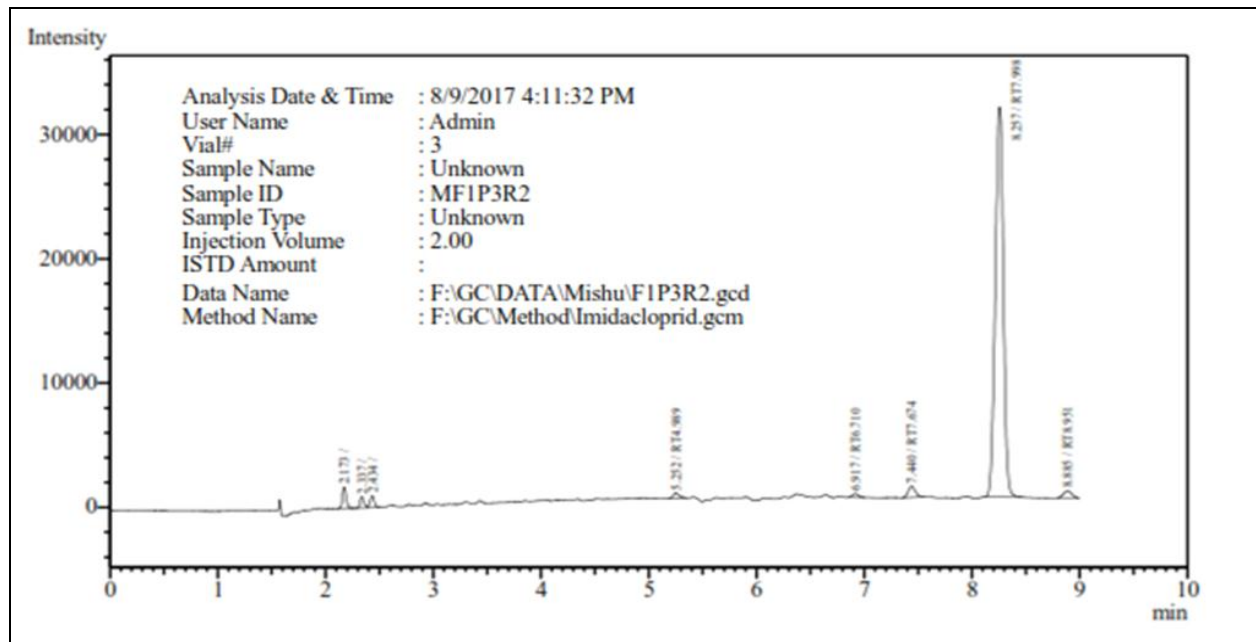

Fig. 3. Chromatogram of dissipation kinetics of imidacloprid in soil of country bean agroecosystem after 1 DAT.

Similarly, Malhat et al. (2012) reported the imidacloprid residues on tomato soil after application of imidacloprid 20\% SC @ 60 ml. per feddan $(1$ feddan $=4200$ $\mathrm{m}^{2}$ ). The concentration of imidacloprid $2 \mathrm{~h}$ after treatment was $2.308 \mathrm{mg} \mathrm{kg}^{-1}$. These residues were below determination limit of $0.03 \mathrm{mg} \mathrm{kg}^{-1}$ at 11 days after the application of pesticide. Malhat et al. (2012) also reported the residues of imidacloprid on grape soil after application of imidacloprid formulation at same dose. But, the initial deposit (1 h after application) of imidacloprid was found $2.829 \mathrm{mg} . \mathrm{kg}^{-1}$. The residue of imidacloprid dissipated to $99.09 \%$ at 11 days after the application of pesticide. These residues were dissipated in grapes to undetectable limits in 12 days after last treatment. Kar et al. (2013) studied the environmental fate of imidacloprid residues on cauliflower curds following 3rd application of imidacloprid (Coragen 18.5 SC) @ 9.25 and $18.50 \mathrm{~g} \mathrm{a.i.} \mathrm{ha}^{-1}$. The mean initial deposits of imidacloprid were 0.18 and $0.29 \mathrm{mg} \mathrm{kg}^{-1}$ on the curds at recommended and double the recommended dosages, respectively. These residues reached below the determination limit of $0.01 \mathrm{mg} \mathrm{kg}^{-1}$ in 3 and 5 days, respectively.

\section{Degradation pattern \& Half-life of imidacloprid on country bean grown soil:}

The degradation kinetics of the imidacloprid in the soils of country bean agroecosystem was determined by plotting residue concentration against time, and the maximum squares of correlation coefficients found were used to determine the equations of best fit curves (Fig. 4). The calculated Half-life value $\left(T_{1 / 2}\right)$ were found $1.88,1.74,1.73,1.56$ and 1.52 days, respectively when applied @ 100, 200, 300, 400 and $500 \mathrm{~g}$ a.i. ha ${ }^{-1}$ (Table 4). 


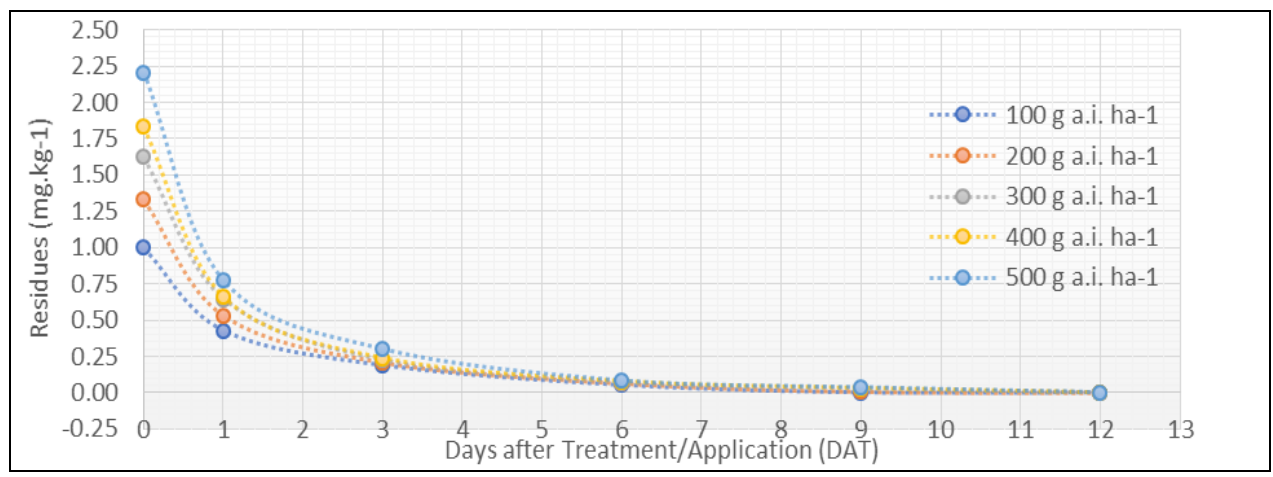

Fig. 4. Semi-logarithm graph showing dissipation kinetics of imidacloprid on country bean grown soil.

Half-life $\left(\mathrm{T}_{\mathrm{I} / 2}\right)$ of imidacloprid on cauliflower curds worked out to be 1.36 and 1.25 days, respectively when applied @ 9.25 and 18.50 g a.i. ha ${ }^{-1}$ (Kar et al., 2013). The dissipation rate of imidacloprid on tomato soils followed first order kinetics.

Table 4. Regression analysis and half-life for the dissipation of imidacloprid

\begin{tabular}{|c|c|c|c|}
\hline $\begin{array}{c}\text { Dose } \\
\left(\mathrm{g} \mathrm{a.i.} \mathrm{ha-1}^{-1}\right)\end{array}$ & $\begin{array}{l}\text { Regression } \\
\text { equation }(\mathrm{Y})\end{array}$ & $\begin{array}{l}\text { Half-life } \\
\text { (days) }\end{array}$ & $\begin{array}{c}\text { Correlation } \\
\text { coefficient }\left(\mathrm{R}^{2}\right)\end{array}$ \\
\hline 100 & $\begin{array}{c}-0.0659 x+ \\
0.6185\end{array}$ & 1.88 & 0.6375 \\
\hline 200 & $\begin{array}{c}-0.0855 \mathrm{x}+ \\
0.7989\end{array}$ & 1.74 & 0.6048 \\
\hline 300 & $\begin{array}{c}-0.1029 x+ \\
0.9636\end{array}$ & 1.73 & 0.5895 \\
\hline 400 & $\begin{array}{c}-0.1132 \mathrm{x}+ \\
1.0574\end{array}$ & 1.56 & 0.5652 \\
\hline 500 & $\begin{array}{c}-0.1357 x+ \\
1.2659\end{array}$ & 1.52 & 0.5617 \\
\hline
\end{tabular}

The half-life of imidacloprid on tomato fruit was 3.30 days after application of imidacloprid 20\% SC @ $60 \mathrm{~mL}$ per $\mathrm{hm}^{-2}$ and also reported half-life of imidacloprid in grapes (Malhat et al., 2012). The half-life of imidacloprid in grapes was found to be 2.70 days. The half-life of imidacloprid in rice straw was 3.50 days following application of imidacloprid @ $300 \mathrm{~mL}$ a.i. $\mathrm{hm}^{-2}$. The kinetics of imidacloprid was described by the equation $C=1.171 \mathrm{e}^{-0.198 t}$ with $\mathrm{R}=0.902$ (Zhang et al., 2012).

Chemodynamics of Imidacloprid spray in country bean agro-ecosystem: Results revealed that deposition of imidacloprid spray volume on plants at different doses was not varied significantly (Table 5). During application 
imidacloprid was not only received by the plants but also it was drifted to other non-target sites, mainly in the air and soil.

Table 5. Fate of Imidacloprid spray volume in country bean agroecosystem

\begin{tabular}{c|c|c|c}
\hline \multirow{2}{*}{$\begin{array}{c}\text { Doses } \\
(\mathrm{mL} / \text { L/Plant })\end{array}$} & $\begin{array}{c}\text { Imidacloprid } \\
\text { Deposited on plant } \\
(\%)\end{array}$ & \multicolumn{2}{|c}{ Imidacloprid lost $(\%)$} \\
\cline { 3 - 4 } & $27.20 \pm 1.21$ & $32.60 \pm 0.95$ & Soil \\
\hline 1.00 & $28.40 \pm 2.03$ & $32.13 \pm 1.03$ & $39.20 \pm 0.36$ \\
2.00 &
\end{tabular}

The results also indicated that the rate of imidacloprid deposit, out of the target site varied differently. The percentage (\%) loss of Imidacloprid in air was much lower than that of soil. But their loss was not greatly differed with different doses of application. Loss of applied imidacloprid through drifting to the air and soil at maximum mature stages of country bean was found as 32.13-32.60\% and 39.47$40.20 \%$, respectively. Loss of sprayed imidacloprid in soil through drifting was higher than the air and target site (plant canopy).

\section{References}

Anhalt, J. C., T. B. Moorman and W.C. Koskinen. 2007. Biodegradation of imidacloprid by an isolated soil microorganism. J. Environ. Sci. Health Part B Pestic. Food Contam. Agric. Wastes. 42(5):509-514.

Asmatullah, S. N. Q. and A. R. Shakoori. 1998. Embryotoxic and teratogenic effects of hexavalent chromium in developing chicks of Gallus domesticus. Bull. Environ. Contam. Toxicol. 61(3):281-288.

Bonmatin, J. M., P. A. Marchand, R. Charvet, I. Moineau, E. R. Bengsch and M. E. Colin. 2005. Quantification of imidacloprid uptake in maize crops. J. Agric. Food Chem. 53(13): 5336-5341.

Bors, A. M., I. Meghea, and A. G. Borş. 2012. New Trends in Pesticide Residues Control and Their Impact on Soil Quality and Food Safety. Pesticides-Recent Trends in Pesticide Residue Assay, 119.

Campbell, S., L. Chen, J. Yu and Q. X. Li. 2004. Adsorption and analysis of the insecticides thiamethoxam and indoxacarb in Hawaiian soils. J. Agric. Food Chem. 53(13): 5373-5376.

Carrington, D. 2012. Pesticides linked to honeybee decline. The Guardian. UK. Retrieved April 7, 2012.

Chensheng, L. U., K. M. Warchol and R. A. Callahan. 2012. In situ replication of honey bee colony collapse disorder. Bull. Insectol. 65 (1): 78-112.

Decourtye, A., C. M. Armengaud, J. Renou, M. Devillers, G. Cluzeau and M. H. Pham Delègue. 2004. Imidacloprid impairs memory and brain metabolism in the honeybee (Apis mellifera L.). Pestic. Biochem. Physiol. 78(2): 83-92. 
Durovic, R. 2011. Procesi koji određuju sudbinu pesticida u zemljištu. Pesticidi $i$ fitomedicina, 26 (1): 9-22.

EFSA (European Food Safety Authority). 2013. Conclusion on the peer review of the pesticide risk assessment for bees for the active substance clothianidin. EFSA J. 11(1):3066.

Gajbhiye, V. T., S. Gupta and R. K. Gupta. 2004. Persistence of imidacloprid in/on cabbage and cauliflower. Bull. Environ. Contam. Toxicol. 72(2), 283-288.

Gervais, J. A., B. Luukinen, K. Buhl and D. Stone. 2010. Imidacloprid Technical Fact Sheet. National Pesticide Information Center. Retrieved 12 April 2012.

Gunther, F.A. and R. C. Blinn. 1955. Analysis of Insecticides and Acaricides. Lit. Publishers Inc. New York. 696 P.

Haque, E., N. A. Khan, S.N. Talapaneni, A. Vinu, J. G. JeGal and S.H. Jhung, 2010. Adsorption of phenol on mesoporous carbon CMK-3: effect of textural properties. Bull. Korean Chem. Soc. 31(6): 1638-1642.

Herms D. A., D. G. McCullough, C. Smitley Sadof, R.C. Williamson and P. L. Nixon. 2009. Insecticide options for protecting ash trees from emerald ash borer. North Central IPM Center Bull. Retrieved April 7, 2012.

Hoskins, W. M. 1961. Mathematical treatment of the rate of loss of pesticide residues. FAO Plant Prot. Bull. 9(163168): 214-215.

Kar, A., K. Mandal, and B. Singh. 2013. Environmental fate of imidacloprid residues (in using QuEChERS technique. Environ. Monit. Assess. 185: 1255-1263.

Laurent, F. M., and K. Rathahao. 2003. Distribution of imidacloprid in sunflowers (Helianthus annuus L.) following seed treatment. J. Agric. Food Chem. 51(27): 8005-8010.

Liste, H. H. 2003. Soil-plant-microbe interactions and their implications for agriculture and environment (Doctoral dissertation, Habilitation thesis, Humboldt University, Berlin).

Liu, W., W. Zheng, Y. Ma, and K. K. Liu. 2006. Sorption and degradation of imidacloprid in soil and water. J. Environ. Sci. Health Part A. 41(5): 623-634.

Malhat, F.M., 1. Abdallah, and L. Hegazy. 2012. Dissipation of imidacloprid ill tomato fruits and soil. Bull. Environ. Contam. Toxicol. 88, 349--351.

Mandal, K., G. S. Chahil, S. K. Sahoo, R. S. Battu and B. Singh. 2010. Dissipation kinetics of $\beta$-cyfluthrin and imidacloprid in brinjal and soil under subtropical conditions of Punjab, India. Bull. Environ. Contam. Toxicol. 84(2):225-229.

Mondal, M.R.I., M.S. Islam, M.A.J. Bhuiyan, M.M. Rahman, M.S Alam and M.H.H Rahman. 2015. Handbook on Agro-technology ( $5^{\text {th }}$ edn). Bangladesh Agricultural Research Institute, Gazipur-1701.

Mukherjee, I. and M. Gopal. 2003. Pesticide residues in vegetable. Int. Proc. Symp. Risk Assess. Pest. Res. Water \& Food. pp. A1-8.

Nunes, G. S., M. L. Ribeiro, L. Polese and D. Barcelo. 1998. Comparison of different clean-up procedures for the determination of $\mathrm{N}$-methylcarbamate insecticides in 
vegetable matrices by high-performance liquid chromatography with UV detection. J. Chromatogr. A. 795(1): 43-51.

Rashid, M. A., T. Rahman, M. S. Hussain M, M. M. Rahaman. 2007. Indigenous vegetables in Bangladesh. In: Chadha ML, Kuo G, Gowda CLL (eds) Proc. 1st int. conference on indigenous vegetables and legumes-prospectus for fighting poverty, hunger and malnutrition. ISHS Acta Hort.752:397-400.

Segura, C., C. Zaror, H. D. Mansilla and M. A. Mondaca. 2008. Imidacloprid oxidation by Photo-Fenton reaction. J. Hazard. Mater. 150(3), 679-686.

Shammi, M., M.M. Rahman, M. A. Islam, M. Bodrud-Doza, A. Zahid, Y. Akter and M. Kurasaki. 2017. Spatio-temporal assessment and trend analysis of surface water salinity in the coastal region of Bangladesh. Env. Sci. \& Pollut. Res. 24(16): 1427314290 .

Sharma, B., A. Kar, K. Mandal, R. Kumar and S. K. Sahoo. 2013. Development and validation of QUECIIERS method for estimation of imidacloprid residue in soil. Food So. 77:1208-T215.

Whitehorn, P. R., S. O. Connor, F. L. Wackers and D. Goulson. 2012. Neonicotinoid Pesticide Reduces Bumble Bee Colony Growth and Queen Production. Science. 336 (6079): 351-362.

Zeljezic, D., A. L. Vrdoljak, N. Kopjar, B. Radic and S. M. Kraus. 2008. Cholinesterase- Inhibiting and Genotoxic Effects of Acute Carbofuran Intoxication in Man: A Case Report. Basic \& Clinical pharmacol. \& Toxicol. 103(4): 329-335.

Zhang, W., F. Jiang and J. Ou. 2012. Global pesticide consumption and pollution: with China as a focus. Proc. Int. Aca. Ecol. and Environment. Sci. 1(2): 125-144. 
